\title{
Valorization of Dacryodes edulis Fruit (Safou) through Improved Drying Procedures, Packaging and Processing
}

\author{
Sali Atanga Ndindeng ${ }^{1, *}$, Zachée Ambang ${ }^{2}$, Noé Woin ${ }^{1}$, Francis Ajebesone Ngome ${ }^{1}$, Stella Atanga Njebu ${ }^{3}$, \\ Delphine Mapie mfu-Lamaré ${ }^{1}$, Walter Nkeabeng Leke ${ }^{1}$, Josephine Mireille Akoa Etoa ${ }^{1}$, \\ Ge raldine Lum. Chi', Violette Tifuh $\mathrm{Mbah}^{2}$
}

\author{
${ }^{1}$ Fruit Program, Reg. Cent. A gric. Res. Nkolbisson, Inst. Agric. Res. Dev. (IRAD), BP 2067, Yaoundé, Cameroon \\ ${ }^{2}$ Dept. Plant biol., Fac. Sci., Univ. Yaoundé-I, Yaoundé \\ ${ }^{3}$ Taless Dry foods and Equipments, BP 6011, Yaoundé, Cameroon
}

\begin{abstract}
The drying of safou is practiced in countries where the crop is grown but dried products are of low quality due to a high rate of rancidity. The drying procedure and the material used for packaging dried safou may be responsible for the high rate of rancid safou. The use of safou powder as an ingredient in the making of biscuits will open up new markets for dried safou especially for sour clones and this may reduce the quantity of rancid dried safou in the market. In order to investigate this, safou fruits were dried using two different procedures; "rapid" and "slow" procedures and then packaged in polyethylene (PE), polypropylene (PP), vacuum (GR) bags and bottles. Sensory evaluation was performed at 1, 15, 30, 60, 90 days after storage. Safou powder from sour and non-sour clones was used as a partial and comp lete substitute of butter in making biscuits and the acceptability of these biscuits tested in comparison with regular biscuits. The data showed that $100 \%$ of the test panelists accepted the form of the slow-dried safou compared to just $30 \%$ for the rapid-dried $\left(\mathrm{X}^{2}=25, \mathrm{df}=1, \mathrm{~N}=36\right)$. After 90 days of storage,safou dried using the rapid procedure and packaged in PE and PP were completely rancid while safou dried using the slow drying procedure and packaged in PE and PP were rated as slightly rancid $\left(X^{2}=19, \mathrm{df}=1, \mathrm{~N}=36\right)$. The panellists rated dried safou packaged in GR and bottle and stored for 90 days as not rancid irrespective of the drying procedure used. Biscuits produced were highly acceptable and no difference was recorded in the acceptability of partial safou biscuits made from sour or non-sour safou powder $\left(X^{2}=0.09, \mathrm{df}=1, \mathrm{~N}=36\right)$. The proportion of consumers who liked the colour, taste and texture of all biscuits made using non-sour safou powder was higher co mpared to those who dis liked or had no opinion about them $\left(\mathrm{X}^{2}=24, \mathrm{df}=1, \mathrm{~N}=36\right)$. Smaller $\left(40 \mathrm{~mm}^{2}\right)$ safou slices dried for $4 \mathrm{~h}$ got rancid faster than those larger $\left(1500 \mathrm{~mm}^{2}\right)$ safou slices dried for $16 \mathrm{~h}$. Vacuum bags and airtight bottles stored dried safou better than PE and PP. Safou powder from sour and non-sour clone can be used directly as a partial substitute of animal fat (butter) in the making of biscuits without going through the costly and laborious oil extraction process.
\end{abstract}

Keywords Dacryodes Edulis, Shelf Life, Quality, Post harvest Loss, Sensory Evaluation

\section{Introduction}

In Cameroon like other less-developed countries, post harvest loss is very high due to inadequate post harvest practices and processing. This is particularly true for Dacryodes edulis fruit (safou) that is highly perishable in nature lasting 2-3 days at ambient conditions [1]. Poor harvesting, handling and storage of fresh fruits is complicat ed since value-chain actors have limited knowledge and resources to ensure product quality and increase shelf life. Methods to increase shelf life and maintain quality of fru its during andafter harvest have been proposed[2]. Irrespective

* Corresponding author:NdindengSaliAtanga

iradpostharvest@gmail.com (SaliAtangaNdindeng)

Published online at $\mathrm{http} / /$ journal.sapub.org/s

Copyright (C) 2012 Scientific \& Academic Publishing. All Rights Reserved of these achievements, storage of fresh fruits could only last for two weeks at ambient conditions. The question one will normally ask is; what beco mes of fresh safou after two weeks have elapsed? For safou to be properly valorised and marketed both locally and abroad, new methods to increase shelf life and add value need to be considered. Production of dried safou will be an attractive alternative. Dried safou can be eaten as it is or be a potential raw material for safou oil production or safou powder for the making of biscuits. However, the dried safou recorded in some drying units are of low quality. This is mainly due to non-uniformity of safou clones used, poor handling and packaging of products. Most dried safoufruits are packaged in low-grade packages like polyethylene that lead to a high level of rancidity (development of off-flavours). In addition, some drying procedures are believed to accelerate the process of product rancidity. It will be important to determine which drying 
procedure produces products that are acceptable by the population and reduces the rate of off-flavour development during storage. Although dried safou is promising, much still needs to be done especially on how to add-value to these dried products via processing into oil or biscuits.

The existence of an interspecific tree-to-tree variation in safoutraits [3] has greatly influenced the marketing of safou since most farmers do not sort their fruits at harvest. It is not uncommon to find a sachet of dried safou with different clones (sour and not sour). Consumers of safou (boiled, roasted and dried) have expressed the desire to eat fruits coming fro $m$ the same clone and being non-sour with a nice aroma [4]. A majority of safou trees growing in Cameroon are not selected cultivars and it is common to find a high quantity of sour cultivars amongst these trees[3]. That's why the International Center in Agroforestry Research (ICRAF) and the Institute of Agricultural Research for Development (IRAD) have started the selection and multiplication of cultivars with desirable traits for distribution to farmers [5];[6]). The question one will ask is; what becomes of this sour safou that is not acceptable by the population? In addition, if most drying units were to adopt proper drying and packaging of safou for long-term storage, what will they do with this product given that the consumption of dried safou at moment is not commonplace in the diet of Cameroonians? The fresh mesocarp of safou contains about $33-65 \%$ oil[7]; about $18-27 \%$ of this oil is linoleic acid[8] and a good amount of minerals like calcium, potassium, phosphorus and magnesium[9]. Safou oil has been used to make biscuits[10] but the oil extraction process is known to be costly and laborious. In addition, there is a huge loss of other nutrients present in the fruit pulp. It will be interesting to evaluate the potential of safou powder from sour and non-sour clones as a substitute of animal fat in the making of biscuits. Furthermo re, test the acceptability of these biscuits in comparis on with regular biscuits.

\section{Materials and Methods}

\subsection{Study Sites}

Fruit preparation, drying, packaging and milling were done at TalessDryfoods and Equipment, Nkolfoulou, Yaoundé. The baking process, sensory evaluations and consumer preference were done at IRAD, NkolbissonYaoundé and during the International Trade Exhibition (PROMOTE 2011) in Yaoundé.

\subsection{Materials}

\subsubsection{Plant Materials}

Sour and non-sour safou clones were harvested from IRA D experimental farm. Two flour types were used; wheat flour bought from the Mokolo market and rice flour produced by milling rice using a corn mill followed by sieving.

\subsubsection{Equip ment}

The following drying equipments were used; Heraeus ${ }^{\circledR}$ D-6450 Hanau drying oven, fruits slicer, fruit washers, knives, scissors, sieves, bowls, boards, rollers, baking oven with temperature and time control buttons, baking tins, packaging materials (polyethylene (PE), polypropylene (PP),

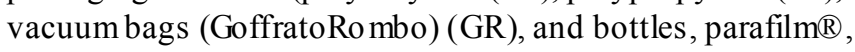
balance, Canon digital camera, plastic sealing machine, vacuum sealing machine.

\subsubsection{Baking Ingredients}

Baking ingredients used include butter, eggs, baking soda, salt, flavouring, powdered milk, baking powder, safou powder (sour and non-sour) and sugar.

\subsection{Methods}

\subsubsection{Preparation of Dried Safou}

The safou fruits were washed with $0.1 \%$ bleach by immersing fruits in solution for 20 minutes after which the fruits were rinsed with distilled water. The fruits were then cut into two halves using a sharp knife. The seeds were removed and the pericarp scraped out.

\subsubsection{First Procedure "Slow Dry ing Procedure"}

For slow dry ing, the pulp was sliced longitudinal to an area of about $1500 \mathrm{~mm}^{2}$ (Fig 1a). The sliced safou was then spread on a drying board and dried in a Heraeus ${ }^{\circledR}$ D-6450 Hanau drying oven at $60^{\circ} \mathrm{C}$ for 16 hour with convectional air circulation.

\subsubsection{Second Procedure"Rapid Dry ing Procedure"}

For rapid drying, fru it pulp was sliced lat itudinal to an area of $40 \mathrm{~mm}^{2}$ using a fruit-slicing mach ine (Fig $1 \mathrm{~b}$ ). The sliced safou was then spread on a drying board and dried in a Heraeus ${ }^{\circledR}$ D- 6450 Hanau drying oven at $60^{\circ} \mathrm{C}$ for 5 hours with convectional air circulation. The dried were then removed, cooled to room temperature and packaged.

\subsubsection{Packag ing of Safou}

The dried safou was then removed, cooled to room temperature and before packaging.Ten grams $(10 \mathrm{~g})$ of safou dried using the two drying procedures were packaged immed iately in PE, PP, GR, and bottles. PE and PP were sealed using a sealing machine, GR was sealed using a Vacuum sealer while bottles were corked and sealed using parafilm®. Sa mp les were evaluated after 1, 15, 30, 60 and 90 days post packaging and storage in a cold dry place at room conditions. All experimentations had 3 replications.

\subsubsection{Preparation of Biscuits}

Three types of biscuits were produced using two kind of safou powder (sour and non sour dried safou milled); one where safou powder was the only lipid source $(0 \%$ butter: $100 \%$ safou), the other where butter was partially substituted 
with safou powder ( $46 \%$ butter: $54 \%$ safou) and that where only butter was the source of lip id ( $100 \%$ butter: $0 \%$ safou). The biscuits with $0 \%$ butter: $100 \%$ safou was named complete safou biscuits; that with $46 \%$ butter: $54 \%$ safou was named partial safou biscuit and that with $100 \%$ butter: $0 \%$ safou was named regular biscuit. To produce the different types of biscuits, $100 \mathrm{~g}$ of sugar, varying proportions of butter: safou $(0: 130 \mathrm{~g}, 60: 70 \mathrm{~g}, 130: 0 \mathrm{~g}), 2$ eggs and $1 \mathrm{~g}$ of salt were mixed. Two hundred (200) $\mathrm{g}$ of wheat flour, $10 \mathrm{~g}$ of powdered milk, $5 \mathrm{~g}$ baking powder and flavouring were then added and mixed well to obtain the homogenous dough. The dough was then wrapped and refrigerated for an hour. The dough was rolled out to $1 / 4$ inches thick on a well-floured surface. The rolled dough was then cut into the same shape and place on a greased sheet and bake at $190^{\circ} \mathrm{C}$ for 10 minutes. Partial safou and regular biscuits were also produced using rice flour produced locally. Biscuits were allowed to cool on a tray and vacuum packaged and evaluated the next day for sensory evaluation. All experiments had three replications.

\subsubsection{Sensory Evaluation}

With the aid of a questionnaire, a trained sensory evaluation panel consisting of 12 persons was asked to score the appearance (form and colour) of dried safou obtained using the rapid and slow drying procedures on a likeness hedonic scale (like, dislike and not sure). The same panel was asked to rank the taste of dried safou packaged in different containers on a rancidity hedonic scale (not rancid, slightly rancid and rancid). These tests were done 1, 15, 30, 60 and 90 days post packaging and storage. Another trained test panel consisting of 12 persons was also asked to score the colour, taste and texture of the biscuits produced on a likeness hedonic scale (like, dislike and not sure). In addition they were to say if the texture was granulated, smooth, crispy or hard. To avoid the influence of packaging material on the choice of the panelists, products were taken out of the packaging containers and placed in dishes before being presented to the test panel. The panelists were not informed about the constituent of the product being tested and all replicated samples were tested. During POMOTE 2011 in Yaoundé, a stand was put in place to sell dried safou produced from the slow and rapid drying procedures. In addition, regular and safou biscuits were also sold. Consumers were presented with dried safou and biscuits to taste and their preference were recorded. The quantity of each type of dried safou sold during the entire period of the PROMOTE 2011 was also recorded.

\subsubsection{Statistical Analysis}

The data was entered into the Statistical Package for Social Sciences (SPSS) version 10. The frequencies of the responses were generated and the percentages computed. The Chi Square $\left(X^{2}\right)$ test was used to compare two independent preferences expressed as proportions of respondents who bought a particular product, liked or disliked a particular product or scored it as rancid, slightly rancid or not rancid. The Chi Square $\left(\mathrm{X}^{2}\right)$ test was also used to compare the proportion of respondents who scored the 4 different types of biscuits based on texture and the acceptability of those biscuits. All statistical tests were done at the $5 \%$ significance level.

\section{Results and Discussions}

\subsection{Safou Drying Procedures and Cons umer Preference of Dried Safou}

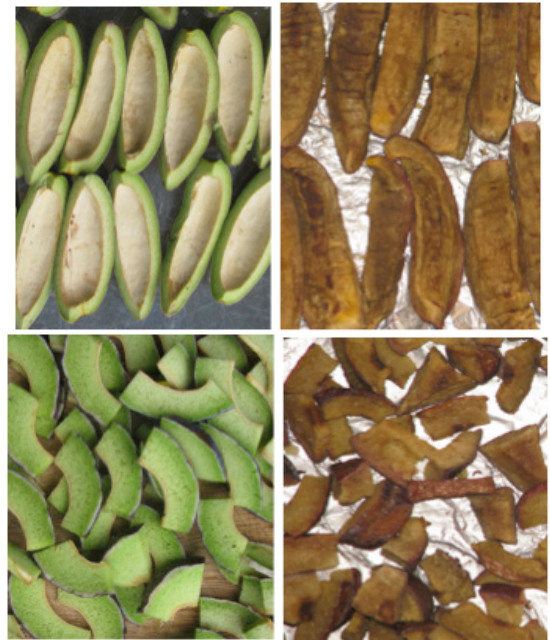

Figure 1. Safou sliced and dried using (A) slow and (B) rapid drying procedures

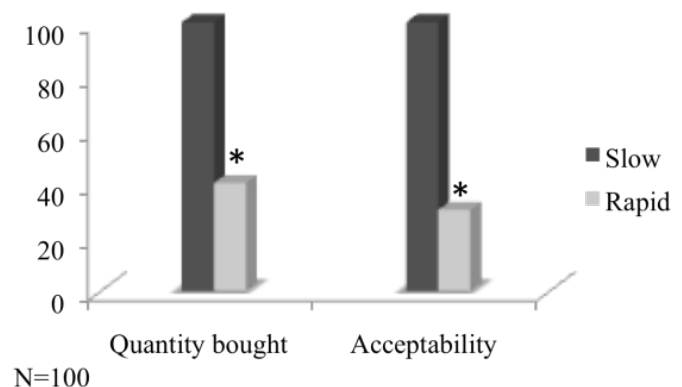

Figure 2. Preference of dried safou from different drying procedure determined from the quantity bought during the 2011 international trade exhibition in Yaoundé and the acceptability of the form by a sensory evaluation panel at IRAD-Yaoundé-Cameroon. * Indicat es the difference is significant at the 0.05 level in that category

Safou dried using the slow drying procedures was preferred by a trained test panel and customers visiting IRAD/Taless Dry Food Partnership stand during the Yaoundé International Trade Exhibition (PROMOTE 2011) compared to that produced using the rapid drying procedure (Fig 1). The main reasons put forward for this preference was the size of the slices and the fact that they could recognize that the product was safou. The slow drying procedure produced longitudinal slices of $1500 \mathrm{~mm}^{2}$ and consumers can easily recognize it as safou while the rapid drying procedure produces slices of $40 \mathrm{~mm}^{2}$, which wasnot easily recognized as safou. The data showed that $100 \%$ of the panel accepted the form of the slow dried safou compared to just 
$30 \%$ for the rapid $\left(X^{2}=25, d f=1, N=36\right)$. The colour of the product was not an important factor influencing consumer preference of dried safou produced using both procedures. One hundred (100\%) of dried safou packs produced using the slow drying procedure were sold at the PROMOTE 2011 stand compared to $40 \%$ of that produced using the rapid drying procedure (Fig 2) $\left(\mathrm{X}^{2}=25, \mathrm{df}=1, \mathrm{~N}=100\right)$. The results obtained at PROMOTE 2011 were similar to observations made at the level of the test panel at IRAD Yaoundé-Cameroon.

\subsection{Safou Drying Procedures, Packaging and the Development of Off-Flavours}

The taste of safou dried using both procedures were considered not rancid (no off-flavour) by the test panel a day after drying and 15 days after drying and packaging in PE, PP, GR and bottles (Fig 3a). Thirty (30) days after dry ing, safou dried using the rapid procedure and packaged in $\mathrm{PE}$ were slightly rancid and the rest were not rancid. Sixty (60) days after drying, most of the safou dried using the rapid procedure and packaged in PE were rancid while those in PP were slightly rancid. All safou dried using the slow procedure was not rancid irrespective of the packaging material used. In addition, all dried safou packaged in GR and bottles were not rancid irrespective of the drying procedure used (data not shown). After 90 days of storage, the safou dried using the rapid procedure and packaged in PE and PP were completely rancid while safou dried using the slow drying procedure and packaged in $\mathrm{PE}$ and $\mathrm{PP}$ were rated as slightly rancid by more than $80 \%$ of the trained panel $\left(\mathrm{X}^{2}\right.$ $=19, \mathrm{df}=1, \mathrm{~N}=36$ ). The panel rated dried safou packaged in GR and bottle as not rancid irrespective of the drying procedure used (Fig 3b)

From the above results, show that safou produced using the rapid procedure get rancid faster than that produced using the slow dry ing procedure. Safou produced using the slow drying procedure is sliced into thin slices and thus the total surface area of the tissue exposed to oxygen is higher than for safou dried using the slow drying procedure. Since safou pulp contains about 33-65\% lip id[7] mostly polyunsaturated fatty acids, increase exposure of the dried pulp to atmospheric oxygen and light may result in the oxidation of these lipids to produce volatile aldehydes, ketones and alcohols that are responsible for the rancid flavour observed[11]. For the food industry, the detection of oxidative off-flavors by taste or smell is the main procedure of deciding when a lipid-containing food is no longer fit for consumption[12]. In this study, we observe that packaging and storage of dried safou in air-deprived or air-tight containers like vacuum bags and bottle respectively minimize the rate of off-flavour development in safou produced using both rapid and slow drying procedures during storage. The greatest inhibitory effect of vacuum and bottle packaging compared to polyethylene (PE) and polypropylene (PP) was probably because they are impermeable to gases, mo isture and aroma. PP is moderate permeable to mo isture, gases and aroma. Although PE is a good moisture barrier, it has relatively high permeability to gases and aroma.

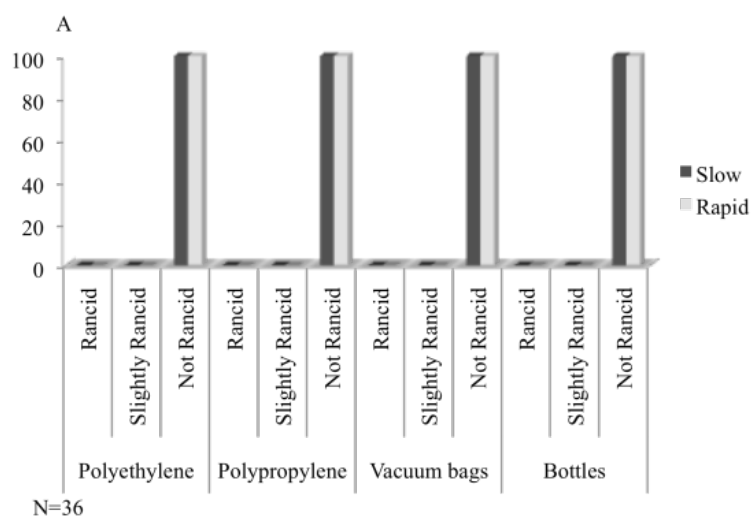

B

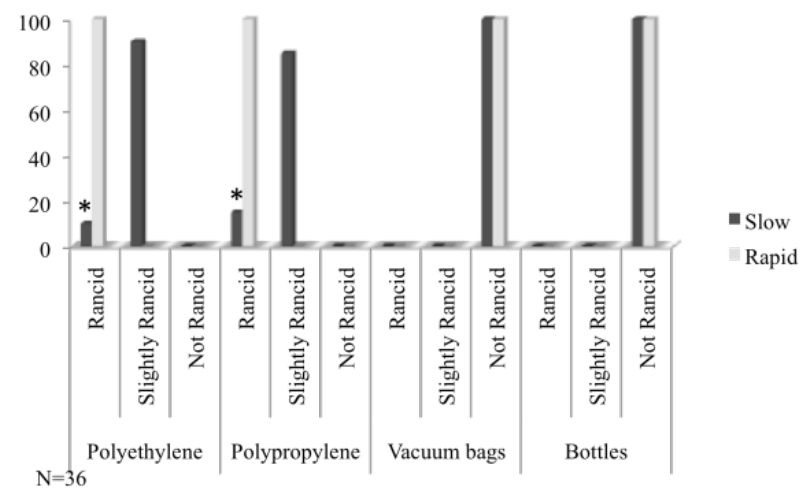

Figure 3. Percentage of consumers who classified safou dried using different dryingprocedures and packaged in different materials on a rancidity hedonic scale (A) a day after drying and packaging and (B) 90 days after drying and packaging. * Indicates the difference is significant at the 0.05 level in that category

\subsection{Safou Powder as a Partial Substitute to Ani mal Fat in The Making of Biscuits}

Powdered dried safouwas effectively used as a partial substitute of animal fat in the making of biscuits (Fig. 4). Consumers' preference for partial safou biscuits made using sour safou was same as that made using non-sour safou clones (data not shown). However, there was a difference in response for complete safou biscuits especially at the levelof the taste. The proportion of consumers who liked the colour, taste and texture of all biscuits made using non sour safou powder was higher co mpared to those who dis liked or had no opinion about them $\left(X^{2}=24, d f=1, N=36\right)$. Un like for non sour safou powder, the proportion of consumers who liked and disliked the taste of complete biscuits made using sour sofou powder was not different (Fig.5) $\left(\mathrm{X}^{2}=0.11, \mathrm{df}=1\right.$, $\mathrm{N}=36$ ).

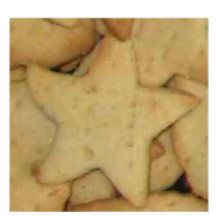

A

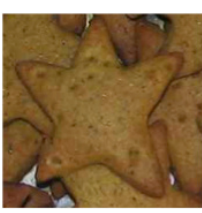

$\mathrm{B}$

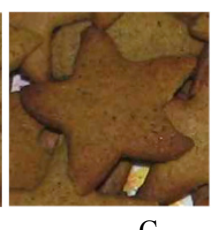

C
Figure 4. Biscuits produced using different proportions of butter and safou powder as lipid source. (A) Regular biscuit (100\% butter: $0 \%$ safou), (B) Partial safou biscuit (46\% butter: $54 \%$ safou), (C) Complete safoubiscuit ( $0 \%$ butter: $100 \%$ safou) 


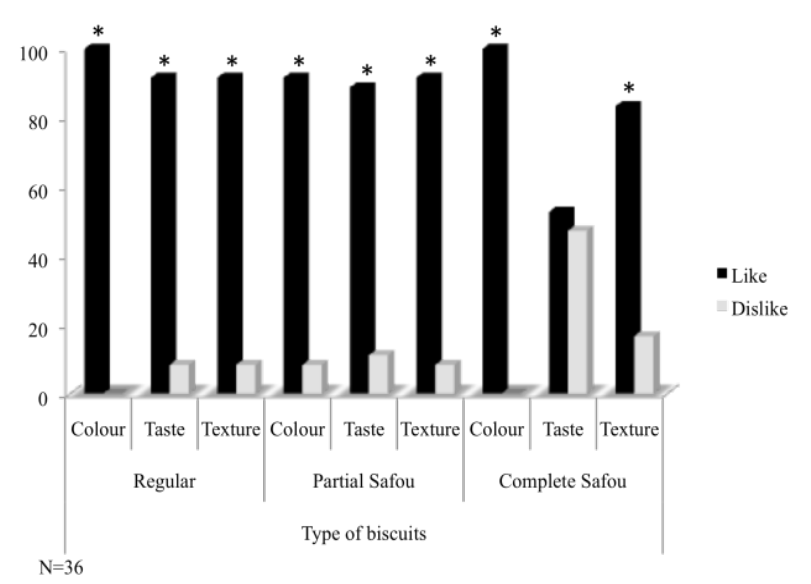

Figure 5. Preference of biscuits produced using butter (regular, $100 \%$ butter: $0 \%$ safou), partial sour safou powder ( $46 \%$ butter: $54 \%$ safou) and complete sour safou powder $(100 \%$ butter: $0 \%$ safou $) .{ }^{*}$ Indicates the difference is significant at the 0.05 level in that cat egory
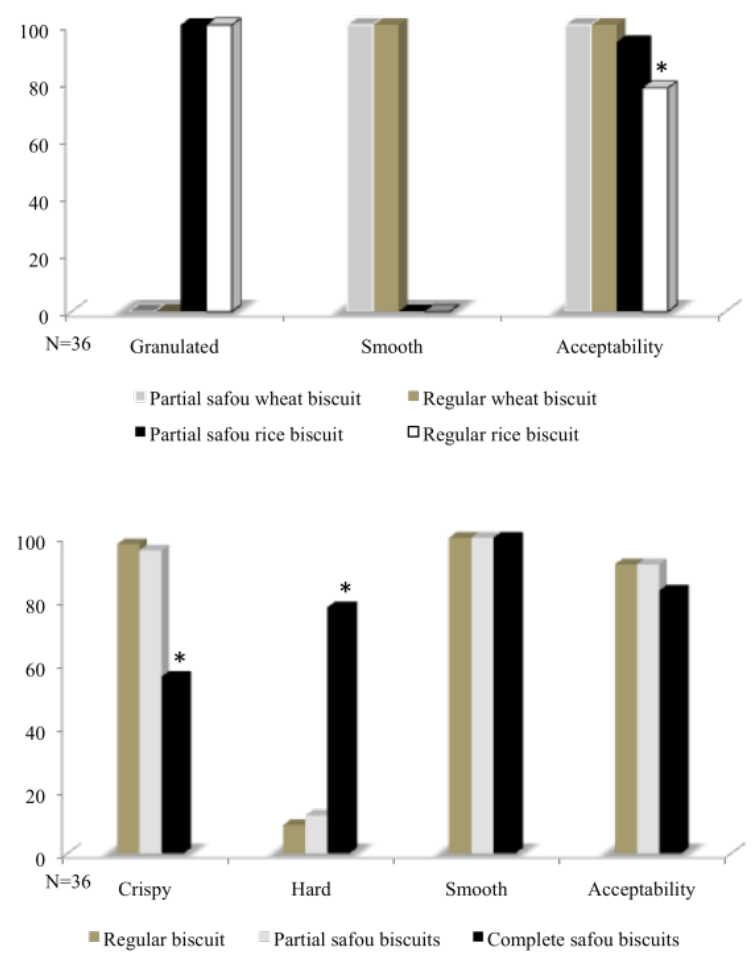

Figure 6. Texture and acceptability of the texture of biscuits determine by a sensory evaluation panel at IRAD Yaoundé-Cameroon for partial safou biscuit ( $46 \%$ butter: $54 \%$ safou), and Regular biscuit (100\% butter: $0 \%$ safou) produced using rice or wheat flour. *Indicates the difference is significant at the 0.05 level in that category

The main reason advanced by consumers was an after-taste after eating the biscuits. A slightly high but insignificant proportion of respondent dis liked the texture of complete safou biscuits irrespective of the type of safou powder used. The main reasons advanced was that these biscuits were not crispy $\left(\mathrm{X}^{2}=16, \mathrm{df}=2, \mathrm{~N}=36\right)$ and hard $\left(\mathrm{X}^{2}\right.$ $=22, \mathrm{df}=2, \mathrm{~N}=36$ ). Biscuits produced using safou flour were rated as smooth while those produced using rice flour were rated as granulated (Fig.6). Respondent generally accepted biscuits produced using both wheat and rice biscuits with or without safou powder but the proportion of those who liked regular rice biscuits was lower (Fig. 6) $\left(\mathrm{X}^{2}=10\right.$, df $=3$, $\mathrm{N}=36$ ). Safou powder improved the acceptability of rice biscuits. The reas on for this improvement may be because safou powder decreased the granulated nature of the rice biscuits produced.

\subsection{Valorisation of Sour Safouas a Substitute of Ani mal Fat In Bakery}

Consumers of safou (boiled, roasted and dried) have expressed the desire to eat fruits coming from the same clone and being non-sour with a nice aroma[4]. Most $D$. edulis trees in Cameroon are growing in the wild (not traceable) and it is common to find a good quantity of acidic safou among the fruits from these trees[3]. Since most of this sour fruit is not acceptable, they are usually left to get rotten, thus aggravating post harvest loss in these species. The result obtained in this study showed for the first time that value could be added to sour safou by using its powder in making safou biscuits. The biscuits were highly acceptable and no difference was recorded in the acceptability of partial safoubiscuits made either withsour or non-soursafou powder $\left(\mathrm{X}^{2}=0.09, \mathrm{df}=1, \mathrm{~N}=36\right)$.

Although the results in this study are similar to those obtain other work[13]; [10], in which safou oil was used as an ingredient for making cookies, the present study demonstrated that the laborious oil extraction process can be avoided and the entire dry powdered fruit pulp used as an ingredient in bakery. It has been shown that the fresh mesocarp of safou contains about 33-65\% oil[7]. Thus incorporation of sour safou powder for the making of biscuits will increase the use of safou and spur production. This will undoubtedly increase the income of rural communities and especially women who are the main value-chain actors involved in safou trade.

In addition, the nutritional benefits the population will get from consuming this product are expected to be high as demonstrated in several studies. The lipid content of safou pulp is between $33-65 \%[7] ;[14]$. This value is considerably higher compared to other fru its such as apple $(0.4 \%)$, guava $(0.4 \%)$, banana $(0.39 \%)$ and pawpaw with traces of oil.

The high lipid content in the fruit pulp is of significant value. Apart from the fact it contains linoleic acid, an important polyunsaturated fatty acid in human food, which can prevent cardiovascular disorder, the oil is also rich in oleic acid that has oxidative stability importance[15]. The protein content of the fruit pulp of safou has been shown to be low (3.24\%), but will make significant contribution in ameliorating protein malnutrition especially in children. Carbohydrate composition $(11.38 \%)$ is moderate but can supply some calories. The fruit pulp is a rich source of mineral elements such as sodium potassium, phosphorus, magnesium, iron, copper and zinc[9]. The pulp of safoucontains linoleic and arachidonic acids, which are the essential fatty acids with the percentage of the linoleic acid, found in the pulp to be $23.17 \%$. Dietary fat rich in linole ic acid prevents disorders such as coronary heart diseases[16]. 
This explains why it is advantageous to use safou powder for the making of biscuits rather than just the oil. However, it will be important to evaluate the effect of the baking process on key nutrients in safou pulp and also study the effect of safou and safou biscuit consumption on the level of serum cholesterol.

\section{Conclusions}

This study has demonstrated for the first time the drying procedure, packaging materials and duration of storage of dried safou that best reduces rancidity of the dried product. Safou sliced into s maller and thin slices got rancid faster than those sliced into larger and thick slices. Vacuum bags and airtight bottles stored dried safou better than PE and PP.

This work also demonstrated the use of safou powder from sour and non-sour clone as a partial substitute of animal fat (butter) in the making of biscuits. Partial safou biscuits made from sour and non-sour safou powder were comparable to regular biscuits with both being highly acceptable. However, complete safou biscuits made using sour safou powder were only moderately acceptable because consumer said eating this biscuit left an after-taste. In addition, the biscuits were rated as hard and not crispy. Value addition to sour safou by using its powder in making safou biscuits is an important finding, as this will likely reduce post harvest loss of these fruits that are not acceptable as boiled, roasted or dried[4]. This action will likely open up new markets for dried safou, reduce the duration of dried safou on market shelves thus reduce the quantity of rancid products in the market. In addition, this action will likely protect biodiversity, as farmers will no longer cut down safou trees that produce sour fruits. The biscuit obtained may be very nutritious and may play a vital role in human health especially in reducing cardio-vascular diseas es.

\section{ACKNOWLEDGEMENTS}

This work received financial assistance fro $m$ the Internati onal Foundation of Science; Grant Number E/3463-3F.

\section{REFERENCES}

[1] Kengue, J., Safou. Dacroydesedulis. International Centre for Underutilised Crops, University of Southampton, UK, 2002.

[2] Ndindeng S.A., Kengue, J., Mbacham W.F., Titanji V.P.K. and Bella-Manga, "Effects of 1-methylcyclopropene treatment on the shelf life and quality of Safou (Dacryodesedulis (G.DON) H.J.LAM",Forests Trees and Livelihoods, vol. 17, no.2, pp. 75-88, 2007.

[3] Leakey R.R.B., Atangana A.R., Kengnni E., Waruhiu A.N.,
Usoro C., Anegbe P.O.,Tchoundjeu Z., "Domestication of Dacryodesedulis in West and Central Africa: Characterization of genetic variation",Forests Trees and Livelihoods, vol. 12, pp. 57-78, 2002.

[4] Ndindeng S. A., Talle. Bigo ga J., Kengue J., Boffa Jean-Marc, "Predictors of organoleptic quality of boiled and dried pulp of safou (D. edulis) and the shelf life of its fresh fruits",Fruits, Vol 67, no2, pp. 127-136, 2012.

[5] Kengue. J., Guide de la culture du safoutier. Editions CLE, Yaounde, 2001.

[6] Akinnifesi, F.K., Leakey, R.R.B., Ajayi, O.C., Sileshi, G., Tchoundjeu, Z., Matakala, P. and Kwesiga, F.R. (Eds.), Indigenous Fruit Trees in the Tropics: Domestication, Utilization and Commercialization. CAB International, Wallingford, England, 2008.

[7] Omoti U. and Okiy D.A., "Characteristics and composition of oil and cake of African pear" Journal of the Science of food and Agriculture, Vol 38, no.1, pp. 67-72, 1987.

[8] KinkélaT.,Kama-NiamayouaR.,Mampouya D., Silou T.,"Variations in morphological characteristics, lipid content and chemical composition of safou[Dacryodesedulis (G. Don) H.J. Lam] according to fruit distribution. A case study",African Journal of Biotechnology,Vol 5, pp. 1233-1238, 2006

[9] Omogbai B. A. and Ojeaburu S., "Nutritional composition and microbial spoilage of Dacryodesedulisfruits vended in Southern Nigeria", Science. World Journal Vol 5, pp. 5-10, 2010 .

[10] Mbofung C.M.F., Silou T. and Mouragadja I., "Characterization of safou and evaluation of its potentialas an ingredient in nutritious biscuits"Forests Trees and Livelihoods, vol. 12, pp. 105-117, 2002.

[11] Karel, M. In Concentration and Drying of Foods, MacCarthy, D., (Ed.),Elsevier Applied Science Publishers: London, UK, pp 37-51, 1986.

[12] Gordon M., In Antioxidants in Food: Practical Applications; PokornyJ., YanishlievaN., and GordonM., (eds.), Woodhead Publishing, Ltd., Cambridge, England, pp 71-84, 2001.

[13] Oluwatooyin F. O.,"Potential of African pear (Dacryodesedulis) as an ingredient in plantain-based composite cookies", Journal of nutrition and Food Science, Vol40, no 1, pp. 39-48, 2010.

[14] Dzondo-Gadet M., Nzikou J.M, Matouba E., Etoumongo A., Linder M., Desobry S." "Characterisation and nutritional interest of safou pulp oil'Process Biochemistry,vol40, pp. 307-312, 2005 .

[15] Ikhuoria E. U. and Maliki M.,"Characterization of Avocado pear (Persea American) and African pear (Dacryodesedulis) extracts". African Journal of Biotechnology, Vol6, pp. 950-952, 2007.

[16] Sher J., Pronczuk A., Hajri T., Hayes K.C.,"Dietary conjugated linoleic acid lowers plasma cholesterol during cholesterol supplementation, but accentuates the atherogenic lipid profile during the acute phase response in hamsters", Journal of Nutrition,vol 133, pp. 456-460, 2003. 